\title{
The Maltese Falcon, or: my Porsche for a Passport!
}

\author{
Jelena Džankić
}

\begin{abstract}
'We didn't exactly believe your story, Miss O'Shaughnessy. We believed your 200 dollars. I mean, you paid us more than if you had been telling us the truth, and enough more to make it all right.' These were the words of Sam Spade played by Humphrey Bogart in the 1941 film 'The Maltese Falcon'. Malta's recent amendments to the Citizenship Act suggest that for the country's policymakers the amount of $€ 650,000$ is just enough 'to make it all right' for investors to purchase the Maltese and by extension the European Union (EU) citizenship. But is cash-for-passport really 'all right', and does it affect the value of citizenship?
\end{abstract}

Magni Berton suggests in his contribution to this Forum that what is wrong with the Maltese law is that ordinary naturalisation is too difficult and discretionary. Indeed, for most applicants, meeting the criteria for ordinary naturalisation takes a long time and a lot of effort. During the years of residence that the applicants spend in their country of destination they make that country the focal point of their lives: they learn its language, its customs and establish social links with other citizens living there. Their claim to citizenship of that country is based - following Shachar - on ius nexi. Hence the integration of such individuals is of high value for citizenship as a public good, as a network of communal contributions and responsibilities, as shared love for the country.

Yet, Magni Berton claims that the rich may as well love the destination country and that money may merely be an instrument for facilitating their access to citizenship. Instead of a 'human investment', which would entail time, establishment of social links, and acquisition of language skills, the wealthy can make a monetary contribution. However, as highlighted in other contributions to this debate, the rich usually do not spend much time in their destination countries. Rather, as Spiro noted, they mostly use the opportunities provided to them by virtue of possessing its passport. Now, what is love in this context? The one who truly loves is willing to wait and invest time and effort. Otherwise, we would not speak about love. Offering money in 
exchange for practical benefits together with a claim of love sounds rather like something else. And that 'something else' is simply wrong.

In justifying investor citizenship programmes, Magni Berton further compares citizenship with stockholding: 'individual citizens are like a jointstock company in which fellow-citizens invest'. This reduces the scope of citizenship, because the interests of stockholders are determined by the share of stocks that they have in the company. In addition to this, stocks are tradable - not only from the government to an individual, but also among individuals themselves.

It makes more sense if, instead of regarding citizenship as stockholding, we compare it to stakeholding, as Bauböck has suggested ${ }^{1}$. A citizenstakeholder is a person who has a fundamental interest in membership in a particular polity (rather than in economic or other benefits for which membership may be instrumental). We can identify such stakeholder citizens by looking at how a person's interest in autonomy and well-being are structurally linked to the collective autonomy (self-government) and well-being (flourishing) of a country. This means that those who have obtained citizenship merely on grounds of investment cannot be stakeholders, because they only have an accidental and instrumental interest in citizenship in a state that offers them a favourable investment environment.

It is worth mentioning that there are different ways in which countries offer citizenship to the rich, which is often overlooked both in the media and in academic circles. ${ }^{2}$ The way in which an investor programme is regulated could potentially turn this instrumental interest of the rich in possessing a passport of a country into stakeholder citizenship. In her initial contribution to this debate, Shachar highlighted the difference between 'golden residence' and 'investor citizenship' programmes. While the former require the investors to reside in their country of destination for a number of years and to undergo a standard naturalisation procedure (including the knowledge of language, customs, etc.) before becoming citizens, the latter is an exchange of a fixed amount of money and citizenship (most governments do run criminal record and due diligence checks of applicants). There is also a third mechanism for turning investors into citizens, which is discretionary

\footnotetext{
1 Bauböck, R. (2009), 'The Rights and Duties of External Citizenship', Citizenship Studies 13 (5): 475-499.

2 Dzankic, J. (2012), 'The Pros and Cons of Ius Pecuniae: Investor Citizenship in Comparative Perspective', Robert Schuman Centre for Advanced Studies, EUDO Citizenship Observatory Working Paper 2012/14, Florence: European University Institute, available at http://cadmus.eui.eu/handle/1814/21476
} 
naturalisation on grounds of national interest. These provisions exist in 22 out of the 28 EU Member States. Such discretionary naturalisation is the prerogative of the state and it is used only in a few cases annually. In several countries, including Austria, discretionary naturalisation has resulted in corruption and secret deals, which tells us that too much discretion can have adverse effects on citizenship.

Even with this in mind, we can find some support for Armstrong's argument that investor citizenship programmes are not always wrong. That is, well-conceptualised 'golden residence' schemes may bring economic benefits to the state while also turning investors into genuine stakeholders. However, such 'golden residence' programmes should not be based merely on real estate purchase, as recently approved by Spain, and they should require more than a compulsory residence of only a few weeks per year as a mechanism of eventually qualifying for citizenship, as they do in Portugal. The argument here is that neither the possession of real estate nor the lack of residence can help the wealthy to establish a true connection with the destination country. Only 'golden residence' programmes that are based on multi-annual investment, jobs for citizens of the destination country, and compulsory residence for the investor before qualifying for citizenship, as is the case in Canada, help the investor to become integrated and interested in the well-being of the citizens of her or his adopted country.

By contrast, the program recently passed by the Maltese government is a 'pure investor citizenship' scheme, which differs from programmes in other EU countries that have recently adopted various 'golden residence' schemes (Bulgaria, Hungary, Portugal, Spain). Besides the crisis-struck Cyprus, which in May 2013 opened several routes to naturalisation on grounds of economic contribution to the state, Malta is the only other European state with such a scheme. The programmes in Malta and Cyprus are thus more similar to the ones in the Caribbean islands - Saint Kitts and Nevis, the Commonwealth of Dominica, and Antigua and Barbuda, all of which operate 'investor citizenship' schemes.

Two things make the Cypriot and Maltese programmes more attractive for investors than those of the Caribbean islands. First, in the former cases the naturalised investor will be granted visa-free travel to 151 (Cyprus) or 163 (Malta) states. This is considerably more than they would have by virtue of possessing the best-ranked Caribbean passport, that of Saint Kitts and Nevis which allows visa-free entry to 131 countries. Second, and more importantly, since in the EU the regulation of citizenship is decided by each Member State for herself, an individual may now obtain EU citizenship for roughly the price of a Porsche 918 Spyder. Hence the investor gains access 
to all the rights stemming from EU citizenship, including free movement and residence within the EU, the right to vote for and stand as a candidate in European Parliament and municipal elections, diplomatic protection, etc. This raises the question of whether it is proportionate and just that access to this array of rights is exchanged for the price of a sports car. Doesn't this dilute the value of citizenship to a tradable commodity, voiding it of the sense of rights and duties and undermining citizens' solidarity? If states sell citizenship, what the buyer gets will no longer look like citizenship at all.

Open Access This chapter is licensed under the terms of the Creative Commons Attribution 4.0 International License (http://creativecommons.org/licenses/by/4.0/), which permits use, sharing, adaptation, distribution and reproduction in any medium or format, as long as you give appropriate credit to the original author(s) and the source, provide a link to the Creative Commons license and indicate if changes were made.

The images or other third party material in this chapter are included in the chapter's Creative Commons license, unless indicated otherwise in a credit line to the material. If material is not included in the chapter's Creative Commons license and your intended use is not permitted by statutory regulation or exceeds the permitted use, you will need to obtain permission directly from the copyright holder.

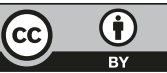

